\title{
Potensi Bakteri Koleksi sebagai Biofertilizer
}

\author{
R. N. Safitri, M. Shovitri dan A. Hidayat \\ Departemen Biologi, Fakultas Ilmu Alam dan Institut Teknologi Sepuluh Nopember (ITS) \\ e-mail: maya@bio.its.ac.id
}

\begin{abstract}
Abstrak-Biofertilizer mengandung mikroorganisme hidup dengan kemampuan melarutkan unsur makronutrien dan memproduksi fitohormon. Konsorsium bakteri merupakan kumpulan dari 2 atau lebih bakteri yang membentuk suatu komunitas dari genus yang berbeda. Agar mendukung aplikasi biofertilizer diperlukan adanya sinergisme antar bakteri. Pada penelitian ini akan dilakukan uji sinergisme dan uji potensi biofertilizer secara kualitatif. Tujuan dari penelitian ini adalah mengetahui sinergisme dan potensi bakteri sebagai biofertilizer. Hasil menunjukkan bahwa dengan deteksi kualitatif keenam isolat bakteri tersebut tidak mampu menambat nitrogen, melarutkan fosfat dan kalium serta tidak dapat memproduksi fitohormon IAA namun dapat bersinergi secara positif.
\end{abstract}

Kata Kunci-biofertilizer, fosfat, kalium, IAA, nitrogen, sinergisme

\section{PENDAHULUAN}

$\mathrm{P}$ ENGGUNAAN pupuk kimia terutama pada sektor pertanian secara berlebihan dapat meningkatkan produktivitas namun dapat pula menyebabkan dampak negatif pada lingkungan yaitu pencemaran air dan tanah [1][2]. Penggunaan pupuk hayati atau biofertilizer merupakan salah satu upaya untuk mengurangi dampak tersebut. Pupuk hayati atau biofertilizer merupakan produk biologi aktif terdiri atas mikroorganisme yang dapat meningkatkan efisiensi pemupukan, kesuburan dan kesehatan tanah. Formula pupuk hayati adalah komposisi mikroorganisme dan bahan pembawa penyusun pupuk hayati (PERMENTAN No. 70 Tahun 2011). Biofertilizer sebagai pupuk biologis berpotensi dalam meningkatkan produktivitas dan keberlanjutan tanah. Hal ini dilaporkan oleh Seed et al., (2015) [3] bahwa produksi timun (Cucumis sativus L.) dengan aplikasi biofertilizer dapat meningkat secara signifikan dibandingkan dengan aplikasi pupuk kimia. Menurut Mohammadi and Sohrabi (2012) [4], mikroorganisme yang umum digunakan sebagai inokulan biofertilizer adalah perombak nitrogen ( $\mathrm{N}$-fixer), pelarut fosfat (P-solubilizer) dan pelarut kalium (K-solubilizer). Sebagian besar bakteri yang dapat digunakan sebagai biofertilizer merupakan bakteri yang dapat berasosiasi dengan perakaran tanaman atau rizosfer.

Pusat Penelitian Gula PTPN X, Kediri, memiliki 6 isolat bakteri dengan genus Azotobacter, Azospirilum, Bacillus, Cellulomonas, Cythopaga dan Pseudomonas. Selama ini 6 genus bakteri tersebut digunakan sebagai konsorsium dalam medium molasse namun belum diketahui sinergisme antar isolat. Pada penelitian ini isolat bakteri koleksi Pusat Penelitian Gula PTPN X akan diuji secara kualitatif kemampuannya sebagai biofertilizer dengan parameter sesuai PERMENTAN No. 70 Tahun 2011 yaitu kemampuan dalam melarutkan fosfat, kalium, penambat nitrogen, produksi fitohormon Indole-3-Acetic Acid (IAA) serta mengetahui sinergisme antar isolat tersebut.

\section{METODOLOGI}

\section{A. Waktu dan Tempat Penelitian}

Penelitian dilaksanakan pada bulan Maret hingga Juli 2018 bertempat di Laboratorium Mikrobiologi Pusat Penelitian Gula, PT. Perkebunan Nusantara X, Jengkol, Kediri serta Laboratorium Mikrobiologi dan Bioteknologi Departemen Biologi, Fakultas Ilmu Alam, Institut Teknologi Sepuluh Nopember Surabaya.

\section{B. Uji Potensi Biofertilizer}

Medium yang digunakan untuk uji kualitatif pelarut fosfat (medium Pikovskaya 31,3 $\mathrm{gL}^{-1}$ ), pelarut kalium (medium Aleksandrov 9,6 gL-), penambat nitrogen (medium JNFb), produksi fitohormon IAA (Nutrient Agar dan Triptofan).

\section{1) Uji Potensi Pelarut Fosfat dan Kalium}

Satu Ose isolat bakteri diinokulasikan dalam $10 \mathrm{ml} \mathrm{NB}$ dan diinkubasi selama 24 jam. Kemudian kertas cakram steril dicelupkan ke dalam kultur dan diletakkan pada medium Pikovskaya dan Aleksandrov padat. Inokulasi isolat dilakukan dengan meletakkan cakram dari 4 isolat berbeda dalam satu medium yang sama (Gambar 1a) sebanyak 3 kali pengulangan. Pengamatan pembetukan zona bening setiap 24 jam sekali dengan pembatasan masa inkubasi selama 3 hari. Pengukuran yang dilakukan berupa rasio zona bening (halo) dengan membandingkan diameter zona bening dan diameter koloni (Gambar 1b) pada temperatur ruangan [5][6]

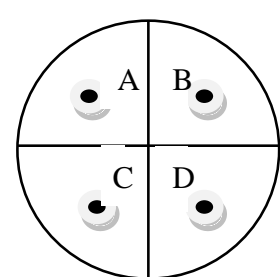

(a)

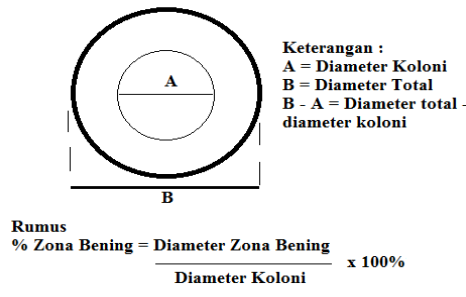

)
Gambar 1. Sketsa Inokulasi Isolat pada Medium Pikovskaya dan Aleksandrov (a). Persamaan estimasi pembentukan zona bening. Huruf A B, C, D adalah Representatif Isolat bakteri (b)

\section{2) Uji Potensi Penambat Nitrogen}

Satu Ose isolat bakteri diinokulasikan dalam $10 \mathrm{ml} \mathrm{NB}$ dan diinkubasi selama 24 jam. Kemudian kertas cakram steril dicelupkan ke dalam kultur dan diletakkan pada 
medium JNFb. Inokulasi isolat dilakukan dengan meletakkan cakram dari 4 isolat berbeda dalam satu medium yang sama (Gambar 1a) sebanyak 3 kali pengulangan. Isolat yang positif dapat menambat nitrogen akan menunjukkan perubahan warna biru disekitar cakram [7].

\section{3) Uji Potensi Produksi Fitohormon IAA}

Pengujian pembentukan IAA dilakukan dengan menginokulasikan isolat pada medium Nutrient Agar (NA) yang disuplementasi triptofan konsentrasi 100 ppm. Medium NA disterilisasi dengan autoklaf bersuhu $121^{\circ} \mathrm{C}$ pada tekanan 1 atm selama 15 menit. Larutan stok triptofan konsentrasi 500 ppm dibuat secara terpisah dengan pembuatan NA dalam akuades steril. Larutan stok diambil sebanyak $20 \mathrm{ml}$ dan dihomogenkan dengan $80 \mathrm{ml} \mathrm{NA}$ steril secara aseptis. Medium NA yang sudah disuplementasi triptofan 100 ppm dituang dalam cawan Petri. Satu Ose isolat bakteri diinokulasikan secara aseptis pada medium. Isolat diinkubasi selama 48 jam pada temperatur ruang. Setelah 48 jam masa inkubasi, isolat ditetesi dengan reagen Salkowski dan diinkubasi kembali selama 30 menit dalam keadaan gelap. Positif mampu memproduksi IAA ditunjukkan dengan perubahan warna isolat menjadi warna merah [8].

\section{Uji Sinergisme}

Isolat ditumbuhkan pada medium Nutrient Agar (NA). Satu ose isolat A digoreskan secara vertikal dalam satu Petri, isolat yang lain digoreskan secara tegak lurus dengan jarak tertentu dan masing-masing isolat bertemu pada satu titik dengan sketsa (Gambar 2) Isolat diinkubasi pada suhu ruang selama 24 jam. Positif sinergi apabila tidak terbentuk zona hambat pada titik yang bersinggungan antar isolat.

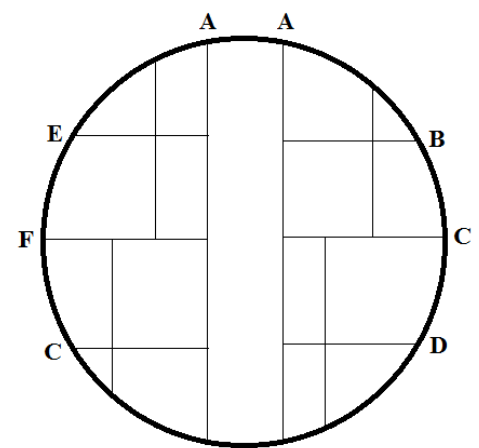

Gambar 2. Sketsa Inokulasi Uji Sinergisme Isolat Potensial Biofertilizer. Huruf A, B, C, D, E, F adalah Representatif Isolat Bakteri.

\section{HASIL DAN PEMBAHASAN}

\section{A. Potensi Bakteri sebagai Biofertilizer}

Berdasarkan hasil uji potensi biofertilizer ternyata seluruh isolat tidak berpotensi dalam dalam menambat nitrogen, melarutkan fosfat dan kalium serta produksi fitohormon IAA (Tabel 1).

Uji kualitatif potensi pelarut kalium dan fosfat dilakukan hingga 4 kali screening pada medium pelarut fosfat dan kalium. Screening awal dilakukan dengan metode spot, namun hasil menunjukkan tidak terbentuk zona bening setelah 4 hari masa inkubasi dengan pengamatan setiap 24 jam. Selanjutnya dilakukan screening kedua, ketiga dan keempat dengan metode cakram. Hasil juga menunjukkan negatif tanpa terbentuk zona bening.

Tabel 1.

Potensi Bakteri sebagai Biofertilizer

\begin{tabular}{|c|c|c|c|c|c|c|c|}
\hline \multirow{2}{*}{$\begin{array}{c}\text { Parameter } \\
\text { Biofertilizer }\end{array}$} & \multirow{2}{*}{\begin{tabular}{|c|}
$\begin{array}{c}\text { Ulangan } \\
\mathrm{Ke}-\end{array}$ \\
\end{tabular}} & \multicolumn{6}{|c|}{ Diameter Zona Bening Isolat Bakteri (mm) } \\
\hline & & \begin{tabular}{|l|} 
Azotobacter \\
\end{tabular} & Azospirilum & Bacillus & Cellulomonas & Cythopaga & Pseudomonas \\
\hline \multirow{3}{*}{ Penambat Nitrogen } & 1 & \multirow{3}{*}{ T, } & \multirow{3}{*}{ 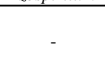 } & \multirow{3}{*}{ ( } & \multirow{3}{*}{ - } & \multirow{3}{*}{ 2 } & \multirow{3}{*}{ 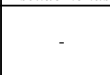 } \\
\hline & 2 & & & & & & \\
\hline & 3 & & & & & & \\
\hline \multirow{2}{*}{ Kelarutan Fosfat } & $\frac{1}{2}$ & \multirow[t]{2}{*}{ - } & \multirow[t]{2}{*}{ - } & \multirow[t]{2}{*}{ - } & \multirow[t]{2}{*}{ - } & \multirow[t]{2}{*}{ - } & \multirow[t]{2}{*}{ - } \\
\hline & 3 & & & & & & \\
\hline \multirow{3}{*}{ Kelarutan Kalium } & 1 & & \multirow{3}{*}{ - } & & \multirow{3}{*}{ - } & \multirow{3}{*}{ - } & \multirow{3}{*}{ - } \\
\hline & 2 & - & & - & & & \\
\hline & 3 & & & & & & \\
\hline \multicolumn{8}{|c|}{ Perubahan Warna (Merah) } \\
\hline \multirow{3}{*}{$\begin{array}{l}\text { Produksi } \\
\text { Fitohormon IAA }\end{array}$} & 1 & \multirow{3}{*}{-} & \multirow{3}{*}{ - } & & \multirow{3}{*}{ - } & \multirow{3}{*}{ - } & \multirow{3}{*}{ - } \\
\hline & 2 & & & - & & & \\
\hline & 3 & & & & & & \\
\hline
\end{tabular}

Uji kualitatif potensi dalam menambat nitrogen dilakukan satu kali dengan masa inkubasi yang lebih lama. Screening dilakukan dengan metode cakram. Hasil juga negatif tanpa terbentuk warna biru disekitar isolat setelah 7 hari masa inkubasi dengan pengamatan setiap 24 jam. Hasil negatif ini seakan kontradiktif dengan yang dilaporkan oleh [9] [10] dan juga yang dilaporkan oleh Pusat Penelitian Gula PTPN X. hasil yang dilaporkan oleh PusLit Gula PTPN X bakteri Azospirillum, Azotobacter dan Cytophaga mampu melarutkan fosfat. Bakteri Bacillus dan Pseudomonas memiliki kemampuan dalam melarutkan fosfat dan kalium (Kolekar et al., 2017) [11] dan bakteri Azospirillum serta Azotobacter mampu menambat nitrogen (Rai and Nabti, 2017) [10].

Ada beberapa hal yang menyebabkan hasil deteksi kalium fosfat negatif antara lain adalah teknik sampling isolat. Pada penelitian ini dilakukan purifikasi dengan metode 16 gores. Dari hasil purifikasi 16 gores ditemukan beberapa bentuk koloni yang berbeda. Hal ini menunjukkan bahwa diawal isolat diduga sudah terkontaminasi. Dari beberapa isolat tersebut diambil satu bisolat yang digunakan selanjutnya untuk deteksi kualitatif. Kemungkinan isolat tersebut bukan isolat yang sama dengan genus tersebut.

Pada Tabel 1 diketahui pula bahwa keenam bakteri tidak dapat memproduksi fitohormon IAA. Uji potensi IAA dilakukan sebanyak 2 kali dengan komposisi medium yang berbeda. Pada screening awal terjadi kesalahan dalam penambahan konsentrasi triptofan hanya 67 ppm dimana konsentrasi triptofan yang harus ditambahkan adalah 100 ppm. Hasil dari screening awal tidak terbentuk warna merah pada isolat setelah ditetesi reagen Salkowski. Screening dilakukan kembali dengan konsentrasi triptofan yang sesuai yaitu 100 ppm namun hasil yang didapat sama seperti screening awal yaitu tidak ada perubahan warna merah pada isolat. Keenam isolat tidak berpotensi memproduksi IAA secara kualitatif. Pada screening IAA yang sudah dilakukan sumber karbon yang didapatkan oleh bakteri berasal dari medium NA Produksi IAA oleh bakteri dipengaruhi oleh faktor lingkungan diantaranya $\mathrm{pH}$, tekanan osmotik dan sumber karbon yang terbatas [12].

Namun demikian, menurut Peraturan Menteri Pertanian No. 70 Tahun 2011 parameter fungsional untuk biofertilizer selain penambat nitrogen, pelarut fosfat, penghasil fitohormon juga dapat menjadi pendegradasi bahan organik (dekomposer). Oleh karena itu, untuk mengetahui potensinya 
sebagai biofertilizer, maka isolat-isolat tersebut perlu diuji dengan parameter yang lain yaitu degradasi karbohidrat, lemak dan protein serta asam organik lain yang bermanfaat bagi pertumbuhan tanaman.

Selulosa merupakan salah satu jenis karbohidrat yang menjadi komponen dasar dari tumbuhan dengan produksi lebih tinggi dari bahan organik lainnya. Zat yang ada dalam tanah dan sisa tumbuhan yang dikembalikan ke tanah sekitar 40-70\% terdiri dari selulosa [13]. Salah satu bakteri yang memiliki kemampuan untuk mendegradasi selulosa adalah Cellulomonas. Langsford et al (1984) [14] melaporkan bahwa bakteri Cellulomonas mampu mensekresikan enzim selulase sehingga memungkinkan pemanfaatan selulosa sebagai sumber karbon. Selain Cellulomonas, Bacillus dan Cytophaga juga mampu mendegradasi selulosa [15]. Bacillus memiliki kemampuan dalam mendegradasi subsrat selulosa bermikrofibril kristalin karena Bacillus merupakan jenis bakteri kemoorganotrof yaitu bakteri yang menggunakan hasil reduksi dan oksidasi senyawa organik sebagai donor elektron [16].

Selain selulosa, lignin adalah biopolimer aromatik yang melimpah kedua di alam [17]. Lignin merupakan karbohidrat kompleks yang memiliki berat molekul tinggi dengan struktur heterogen dan mengandung alkohol sehingga sulit untuk di degradasi [18]. Sekitar 30\% material pohon adalah lignin yang berfungsi sebagai penyedia kekuatan fisik pohon, pelindung dari biodegradasi dan serangan mikroorganisme [13]. Salah satu genus bakteri yang mampu mendegradasi lignin adalah Pseudomonas [19]. Kemampuan bakteri dalam mendegradasi kedua polimer karbohidrat tersebut merupakan parameter lain dari biofertilizer sesuai PERMENTAN No. 70 Tahun 2011. Isolat yang dipurifikasi dalam penelitian ini bisa saja berpotensi sebagai biofertilizer dengan parameter yang berbeda sehingga perlu dilakukan uji lanjutan.

\section{B. Sinergisme Bakteri}

Walaupun potensi dari masing-masing isolat sebagai biofertilizer dengan parameter penambat nitrogen, pelarut fosfat dan kalium serta penghasil IAA adalah negatif (Tabel 2) namun penelitian tetap dilanjutkan dengan uji sinergisme sebagai dasar pembentukan konsorsium. Hal ini karena masih ada peluang bahwa isolat tersebut mampu berperan positif untuk kesuburan tanah. Hasil menunjukkan bahwa keenam isolat tersebut bersinergi secara positif yang terlihat dari tidak terbentuknya zona hambat (Gambar 3). Uji sinergisme adalah uji yang dilakukan untuk mengetahui interaksi positif antara dua atau lebih bakteri yang hidup bersama dan menggunakan sumber nutrisi yang sama. Uji sinergisme dilakukan sebelum pembuatan konsorsium. Menurut Nugroho dan Hidayah (2010) [20], konsorsium bakteri merupakan kumpulan dari dua atau lebih bakteri yang membentuk suatu komunitas dari genus yang berbeda.

Aplikasi biofertilizer biasanya dalam bentuk konsorsium, karena setiap anggota konsorsium dapat berperan pada lingkungan masing-masing. Sinergisme menjadi faktor utama yang diperlukan bakteri agar mampu bekerja sama dengan baik. Sinergisme merupakan interaksi mikroba yang bersifat kooperatif namun belum diketahui hubungan langsung antara sinergisme bakteri dan ketersediaan nutrisi dengan peralihan interaksi bakteri dari sinergisme menjadi antagonisme [21].

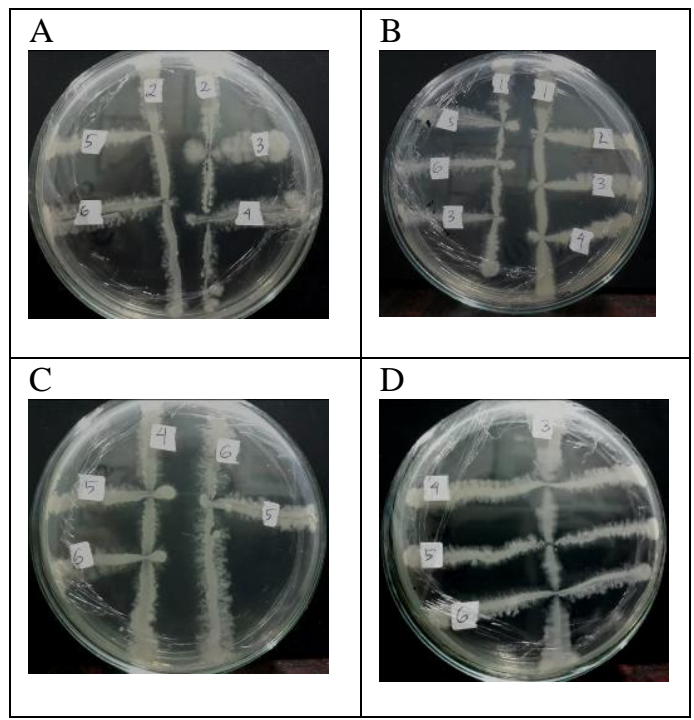

Gambar 3. Sinergisme Pertumbuhan Bakteri pada Medium NA selama 24 jam Masa Inkubasi yang Terlihat Saling Tumpang Tindih. (A) Sinergisme Isolat 2 terhadap Isolat 3,4, 5 dan 6. (B) Sinergisme Isolat 1 terhadap Isolat 2, 3, 4, 5 dan 6. (C) Sinergisme isolat 4 terhadap Isolat 5 dan 6 serta Isolat 6 terhadap 5. (D) Sinergisme Isolat 3 terhadap Isolat 4, 5 dan 6.

Tabel 2.

Sinergisme antar Bakteri

\begin{tabular}{|c|c|c|c|c|c|c|}
\hline Isolat & Azotobacter (I) & Azospirilum (2) & Bacillus (3) & Cellulomonas (4) & Cythopaga (5) & Pseudomonas (6 \\
\hline Azotobacter (I) & & + & + & + & + & + \\
\hline Azospirilum (2) & + & & + & + & + & + \\
\hline Bacillus (3) & + & + & . & + & + & + \\
\hline Cellulomonas (4) & + & + & + & & + & + \\
\hline Cythopaga (5) & + & + & + & + & & + \\
\hline Pseudomonas (6) & + & + & + & + & + & \\
\hline
\end{tabular}

\section{KESIMPULAN}

Isolat bakteri Azotobacter, Azospirillum, Bacillus, Cellulomonas, Cytophaga dan Pseudomonas tidak mampu menambat nitrogen, melarutkan fosfat dan kalium serta memproduksi fitohormon IAA namun dapat bersinergi secara positif.

\section{DAFTAR PUSTAKA}

[1] S. K. B. D. Roychowdhury, M. Paul, "A Review on the Effects of Biofertilizers and Biopesticides on Rice and Tea Cultivation and Productivity," Int. J. Sci. Eng. Technol., vol. 2, no. 8, 2014.

[2] B. C. M. and P. K. R. M.N. Saha, A.R. Saha, "Effect of Long Term Jute Rice Wheat Cropping System on crop yield and fertility," in Long Term fertility Experiments in Rice Wheat Cropping Systems, Abrol., 2000, p. 94-104.

[3] and P. H. A. K.S. Seed, S.A. Ahmed, S.A., I.A. Hassan, "Effect of Bio-Fertilizer and Chemical Fertilizer on Growth and Yield in Cucumber (Cucumis sativus L.) in Green House Condition," Am. J. Agric. Environ. Sci, vol. 15, no. 3, 2015.

[4] K. M. and Y. Sohrabi, "Bacterial Biofertilizers For Sustainable Crop Production: A Review," ARPN J. Agric. Biol. Sci., vol. 7, no. 5,2012

[5] dan M. H. G.A.K. Sutariati, T.C. Rakian, Agustina, N. Sopacua L. Mudi, "Kajian Potensi Rizobakteri Pemacu Pertumbuhan Tanaman yang diisolasi dari Rizosfer Padi Sehat," J. Agroteknos, vol. 4, no. 2, 2014.

[6] K. K. G. and P. B. Desai, "Rhizobacteria of sugarcane: In vitro 
screening for their plant Growth Promoting potentials," Res. $J$ Recent Sci., vol. 3, pp. 52-58, 2012.

[7] J. A. T. K.J. Downing, G. Leslei, "Biocontrol of the Sugarcane Borer Eldana saccharina by Expression of the Bacillus thuringiensis cry1Ac7 and Serratia marcescens chiA Genes in Sugarcane-Associated Bacteria," Appl. Environ. Microbiol., vol. 66, no. 7, pp. 2804-2810, 2000.

[8] F. T. Kholida and E. Zulaika, "Potensi Azotobacter sebagai Penghasil Hormon Pertumbuhan Auksin," J. Sains dan Seni ITS, vol. 4 , no. 2, 2015.

[9] H. K. P. and K. B. S. S.S. Kolekar, P.D. Desai, "Study Of Phosphate Solubilizing Microorganisms with Biofertilizer Potential," Int. J. Pharma Bio Sci., vol. 8, no. 2, pp. 751-757, 2017.

[10] A. R. and E. Nabti, Microbial Strategies for Vegetable Production. Springer International Publishing, 2017.

[11] P. and A. C. R. K. Lingakumar, V. Thangapandian, D. Prabhu, "Isolation and Characterization of Antibiotics Producing Actinomycetes from Soil Samples of Senbagadaruvi in Western Ghats," Biosearch Bull., vol. 1, no. 4, 2011.

[12] R. R. S. Spaepen, J. Vanderleyden, "Indole- 3-Acetic Acid in Microbial and Microorganism-Plant Signaling," FEMS Microbiol. Rev, vol. 31, pp. 425-448, 2007.

[13] H. G. S. and K. Schmidt, Microbiology Six Edition. (Diterjemahkan oleh Tedjo Baskoro). Yogyakarta: Gajah Mada University Press, 1994.
[14] R. A. J. W. M. L. Langspord, N.R Gilkes, W.W. Wakarchuk, D.G. Kilburn, R.C. Miller, "The Cellulase System of Cellulomonas Fimi," J. Gen. Microbiol., vol. 130, pp. 13671376, 1984.

[15] P. S. P. and S. S. Marhawa, Biotechnology in Agriculture and Food Processing Opportunities and Challenges. CRC Press: Taylor and Francis Group, 2014.

[16] E. H. dan K. Hairiah, Biologi Tanah, Landasan Pengolahan Tanah Sehat. Yogyakarta: Pustaka Adipura, 2009.

[17] M. S. and M. H. N.H.A. Rahman, N.A.A. Rahman, "Production of ligninolytic enzymes by newly isolated bacteria from palm oil plantation soils," Bioresour, vol. 8, no. 4, pp. 6136-6150, 2013.

[18] J. M. and A. K. J. Perez, T.D.L. Rubia, "Biodegradation and biological treatment of cellulose, hemicellulose and lignin: An overview," Int. Microbiol, vol. 5, pp. 56-63, 2001.

[19] D. S. and S. V. Sasikumar, V. Priya, C. Shiv Shankar, "Isolation and Preliminary Screening of Lignin Degrading Microbes," $J$ Acad. Ind. Res., vol. 3, no. 6, 2014.

[20] C. N. dan Hidayah, "Penyisihan Logam Chrom Menggunakan Konsorsium Mikroorganisme," Ilm. Tek. Lingkung., vol. 1, pp. 16-19, 2010.

[21] S. Y. Deng, Yi J. and Wang, "Synergistic Growth in Bacteria Depends on Substrate Complexity," J. Microbiol., vol. 54, no. 1, pp. 23-30, 2016. 